\title{
12 Using evidence for tobacco control in West Africa
}

\author{
Papa Yona Boubacar Mane, Abdoulaye Diagne \\ and Salifou Tiemtore
}

\section{Summary}

The marketing of tobacco products in poor countries is intensifying. Despite their commitment, in 2010, the 15 countries that make up the Economic Community of West African States (ECOWAS) were still far from a legislative environment conducive to tobacco control. This case study focuses on the application of the World Health Organization Framework Convention on Tobacco Control (FCTC) in West Africa, and how the use of action research to generate evidence and the creation of consensus between the different stakeholders involved in tobacco control can change policy. The process was supported through an action-research process led by the Consortium for Economic and Social Research, based in Senegal, working closely with ECOWAS. Research was conducted in each country, tax rates were modelled, and the situation and possible taxation rates workshopped with stakeholders, including members of the ECOWAS legislature. The evidence produced and the actions undertaken have contributed to the adoption of a new law on tobacco control in Senegal and a new directive on the taxation of tobacco products in the ECOWAS area, which is now better able to comply with the provisions of the FCTC.

\section{Background}

Tobacco control is a global public health priority. According to the World Health Organization (WHO), smoking kills more than five million people per year worldwide (WHO, 2015). If nothing is done, by 2030, the number of tobacco-related deaths per year will double. More than $40 \%$ of these deaths will occur in developing countries (Goodchild et al., 2018). Strong tobacco control policies are leading to a decline in consumption in developed countries (Chaloupka et al., 2010). This is leading to an intensification of tobacco marketing in poor countries, shifting the future burden of tobacco-related mortality and morbidity to developing countries (IARC, 2011). Under the aegis of the WHO, the international community has decided to take action through the WHO Framework Convention on Tobacco Control (FCTC), which was signed in 2003. All 15 countries that are part of the Economic Community of West African States (ECOWAS) have ratified this framework convention. 
Despite their commitment to tobacco control, in 2010, these 15 countries were still far from a legislative environment conducive to tobacco control. National laws for control were either non-existent, incomplete or not enforced. Tax policies were far from sufficient to reverse the trend of increasing tobacco consumption or to control tobacco use. This was due to two main constraints. First, tobacco industry lobbying has been successful in countering or circumventing any laws or regulations made by states. Second, there was a lack of knowledge about the use of tax policy as an effective means of tobacco control and only timid reforms undertaken in this field by tax administrations. In addition, countries ignored the policies of their neighbours, even though they belonged to ECOWAS and some are also part of the West African Economic and Monetary Union (WAEMU).

Other factors were that civil society had not seen the potential of a tobacco tax and researchers were not interested in the issue. Meanwhile, the regional directives that defined the taxation of tobacco products by ECOWAS and WAEMU member states proposed a type of tax, tax rates, and a tax base that did not promote an effective tax policy.

On a global scale, there is renewed interest in protecting health through tobacco control. Since their engagement by the FCTC, ECOWAS countries have increasingly participated in major international meetings on health and tobacco, including the Conference of the Parties to the WHO FCTC and the World Tobacco Conference. This has raised awareness in ECOWAS countries of the challenges of tobacco control and of the need to set up an appropriate framework for the transposition of the WHO Framework Convention. It is in this context that these countries have implemented changes in their tobacco control environment. This chapter presents the process of implementing these changes through a participatory approach based on action research.

This case study focuses on the application of the Framework Convention in West Africa, and the development and passing of a directive with much more punitive tax rates on tobacco. It demonstrates how the use of action research to generate evidence and the creation of consensus between the different stakeholders involved in tobacco control can change policy. The evidence produced and the actions undertaken have contributed to the adoption of a new law on tobacco control in Senegal and a new directive on the taxation of tobacco products in the ECOWAS area, which is now better able to comply with the provisions of the FCTC.The process was supported through an action-research process led by the Consortium for Economic and Social Research (CRES) ${ }^{1}$ based in Senegal.

An earlier CRES-led action-research project ran from 2011 to 2017. The research for the case study underlying this chapter used the following methodology. Initially, a literature review was conducted on the taxation of tobacco. The various reports and outputs produced by the previous action-research project were analysed to understand the context and environment of tobacco control, the process of adopting the new directive, the various challenges facing ECOWAS countries and the main results of that action-research project. Following the literature review, nine people were interviewed: the ECOWAS representative and the director of CRES (the two champions in this case study), two representatives of research institutes, 
two representatives of tax administrations, a representative from WAEMU, and representatives from a tobacco control focal point and from a civil society organisation. A questionnaire was submitted to respondents a week in advance. The questions were discussed in a telephonic interview where the respondent lived outside Senegal, and in a face-to-face interview where the respondent lived in Senegal.

\section{The evolution of the tobacco control process}

\section{The institutional context}

Unlike other cases in this book, this case has a regional dimension. WAEMU and ECOWAS play a growing role in West Africa, particularly in a strategic aspect of tobacco control, namely tobacco taxation. The ECOWAS and WAEMU commissions are the bodies that lead any tax change process in the region. Any draft new directive must be prepared by a technical committee of experts from the member states, which is submitted to the Council of Ministers. The ECOWAS Commission mobilised participants for the regional conferences and provided financial support for the events.

The role of the tax and customs units of national ministries of economy/ finance is crucial in any changes to taxation policy. Staff of these ministries analyse the technical aspects of any policy change and make proposals to the ministry for a draft law, decree or directive.

Civil society organisations initiated the fight to protect people's health from the harm of tobacco use, and so also play a key role in tobacco control.A particularity of the taxation of tobacco in West Africa was the lack of country-level studies and data. Research centres and national statistical institutes played an important role in filling these gaps, in collaboration with tax and customs administrations.

\section{Moving from local and national actions to regional}

\section{Initial work in Senegal}

Figure 12.1 shows a timeline for the evolution of the process that led up to the adoption by ECOWAS and WAEMU of a new tobacco directive in 2017. It started in 2006 with an African tobacco situation analysis (ASTA), ${ }^{2}$ funded by the Canadian International Development Research Centre (IDRC) and the Bill and Melinda Gates Foundation. A political mapping approach was used to develop a situation analysis to understand the factors that determine success in tobacco control in 10-14 African countries. This enabled each country to clearly understand the broader context in which their tobacco control priorities are situated. The next step was for each country to work on an immediate action plan to achieve one or two priorities of their choice. The programme required proposing projects that combined research and action.

CRES was a participant in the ASTA research and, in preparing their action plan bid, CRES organised a workshop in 2006 to choose between different 


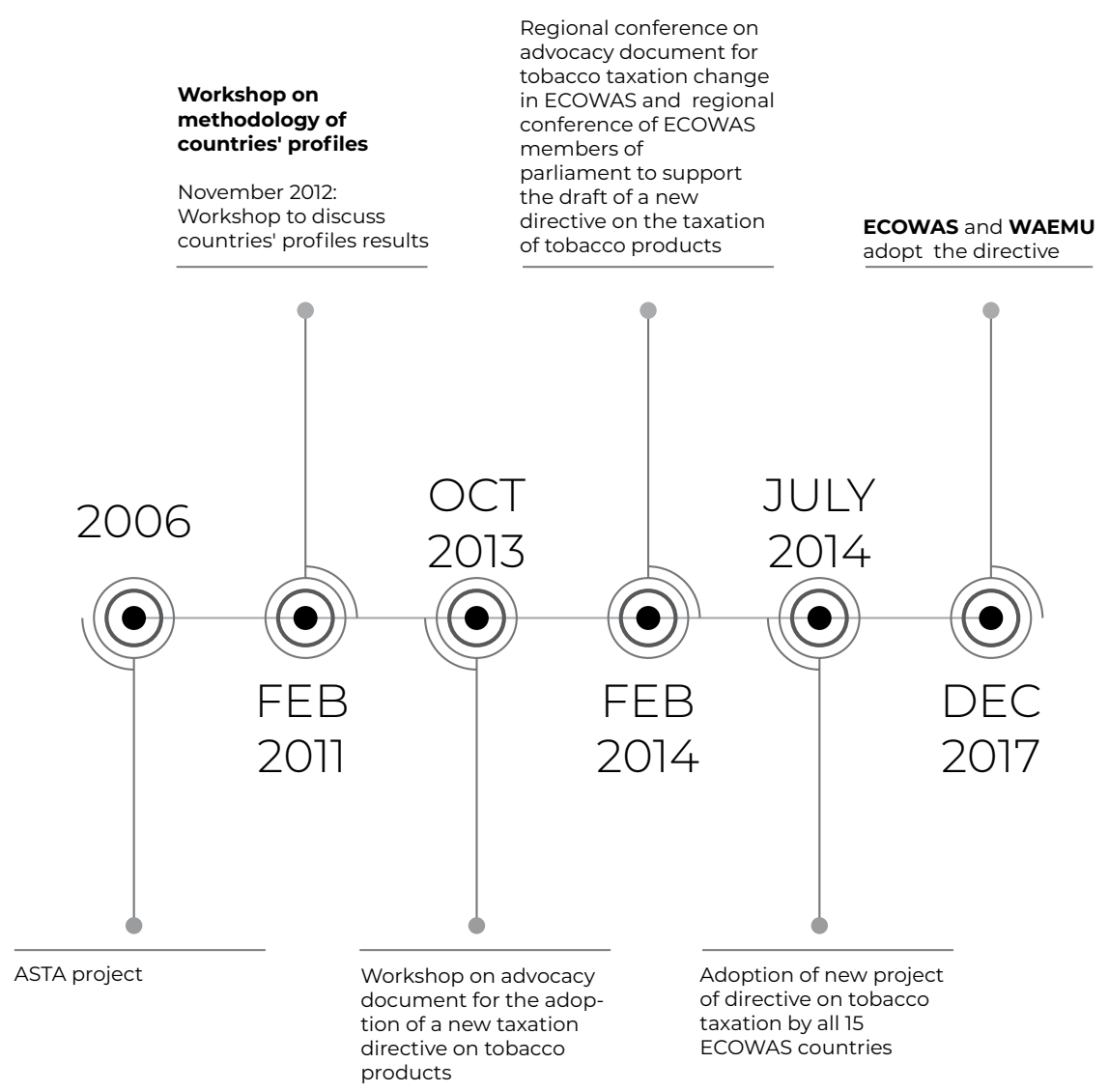

Figure 12.1 Milestones in the ECOWAS new tobacco fiscal directive productsess

Source: Author generated.

priorities. The two priorities selected were Facilitating the Adoption of a Law Responding to the Legislative Need Relating to the Framework Convention on Tobacco Control in Senegal, and Strengthening the Tobacco-Free City of Touba. The first project involved working closely with the Senegalese Ministry of Health and other stakeholders to develop a new draft law on tobacco control. A draft bill was produced in 2011. However, The Bill on the Manufacture, Packaging, Labelling, Sale and Use of Tobacco was only adopted by the National Assembly of Senegal on 14 March 2014 and the implementing decree was signed in July 2016, subsequent to some of the regional work described later.

The second CRES-led ASTA project focused on measures to ban tobacco which have existed for several decades in some religious cities in Senegal such as Touba. As a religious centre of the Mouride Muslim Brotherhood, Touba's 
influence extends to several other cities and towns spread throughout Senegal, some of which are under the direct authority of the Khalife of Touba. Outside the Mouride religious cities, there are networks of disciples throughout the country and abroad who convey the religious directives and recommendations from Touba. This network would be influenced by a tobacco ban measure in Touba (ASTA Project Technical Report, 2010). Through a mapping of local actors involved in tobacco control, grassroots associations came to support such a measure and a prefectural decree was drafted by the local authorities in 2010 for Touba to move from an unwritten tobacco ban to a formal ban.

\section{Moving to a West African approach}

After raising awareness among part of the population and authorities on the need to formalise laws to counter tobacco use in Senegal, CRES decided to widen its scope and look at more effective taxation on tobacco products across the region as a key control measure. As tax policy for the region is governed by ECOWAS, funding was obtained from IDRC for another action-research project in West Africa on tobacco taxation, again with CRES as the project manager. Key stakeholders were identified and brought into the project, notably the chairman of the Customs Commission of ECOWAS. The design and methodology were developed, a steering committee was established in each country and regionally to oversee the project and a scientific committee was set up as the validation body for the documents and procedures.

A first research methodology workshop took place in February 2011 to look at regional decision-making mechanisms, taxation experiments and the levers of the tobacco control strategy. Participants included representatives from each of the 15 ECOWAS member states, the two regional economic communities and technical and financial partners active in the fight against tobacco.

The workshop confirmed the lack of national information on tobacco taxation and the need to take stock of the taxation of tobacco products in the region, including information on the consumption, production, marketing and taxation of tobacco products.

A multidisciplinary research team was set up in each of the 15 countries in 2011. To ensure rigorous data collection and analysis, an academic researcher was appointed as team leader. In addition, there was an official from the tax administration, an official from the customs administration and a statistician, making it easier to collect the required tax and customs data in each country. The methodology for collecting and analysing data was shared with all stakeholders and validated at a sub-regional workshop held in Ouagadougou, Burkina Faso, in November 2012. These teams coordinated the research and ensured the consistent application of methodologies for the collection and drafting of country profile documents, including conducting a survey using the same methodology in all ECOWAS countries to determine the evolution of cigarette prices in the retail trade. 
Subsequently, a conference of decision makers was held in Ouagadougou from 26 to 28 November 2012, with the aim of making decision makers aware of the similarities and differences in tobacco taxation policies and practices in the West African region and to determine ways in which they can use the economic unions to harmonise policies and practices. Representatives of each of the 15 ECOWAS member states attended. Each country's ministry of finance and the focal point on tobacco control in the health ministry of each country were represented. The two regional economic communities were also represented by the commission, which is responsible for changing tax directives. Other technical and financial partners active in tobacco control participated in the workshop. One of the major outcomes of this conference was the recommendation to move towards the adoption of new regional directives on the taxation of tobacco products. The ECOWAS and WAEMU commissions provided guidance on the procedure required. This involved draft guidelines being prepared by a technical committee of experts from member countries and submitted to the Council of Ministers. This technical committee is the only body authorised to draw up directives and must be convinced of the need for a change in tax policy, based on solid arguments and evidence. After these directives have been approved by the ECOWAS Council of Ministers, they are submitted to the Council of Presidents.

A position paper was then developed by CRES to support a change in tobacco taxation in the ECOWAS region. This advocacy paper compared the tax situation in ECOWAS countries, drawn from the country profiles, with the tax situation in other countries and economic areas around the world (WHO, 2015). In October 2013, a regional workshop was held to discuss and refine the first draft of the argument. This workshop was attended by several academic researchers and ECOWAS and WAEMU regional organisations.

Once the document was finalised, a regional conference was organised in Abidjan, Côte d'Ivoire, in February 2014 to share the findings. It was attended by representatives of the tax and customs administrations, ministries of health, parliamentarians from WAEMU and ECOWAS, civil society and international organisations including the WHO and the World Bank. At that conference, participants discussed the gap that existed between taxation of tobacco products in West African countries at that time and potential effective taxation. The discussions led to consensus amongst stakeholders on the need to prepare a preliminary proposal for a new directive.

In parallel with the conference of technical staff, an advocacy conference was held with parliamentarians from ECOWAS and WAEMU to present them with the arguments in favour of a change of directive and gain support for adoption. The parliamentarians appreciated the initiative and agreed to support the adoption of the preliminary draft directive, which they embodied in a signed declaration. 


\section{Box 12.1 Tax categories}

There are taxes that are common to all goods and services, such as VAT and customs duties, and there are so-called excise taxes that are only applied to certain products such as tobacco products. Excise taxes fall into two categories. An ad valorem tax is a tax that is applied to a value. The authority sets a rate or range of rates to be applied to a given value called the tax base. For example, in the ECOWAS region, countries apply the rates set on the producer price, that is the amount that the tobacco industry declares as the sum of its production costs and profits.

The second category of tax is called a specific tax. It corresponds to a fixed amount that the authority levies on cigarette sales, regardless of the price of the tobacco or cigarettes. In Gambia, for example, for any sale of a packet of 20 cigarettes, the tax authority charged five dalasi, regardless of the price. Sometimes the two types of taxes are combined in the same country.

Meanwhile, CRES developed models of combinations of tax types and rates that could lead to higher prices, higher tax revenues and lower consumption (see Box 12.1). A proposal for a combination of two types of taxes was put forward, taking into account the literature, the results of the modelling and, above all, the arguments of the technicians who would have to apply the tax changes. It was recommended that the minimum tax rate of $15 \%$ of the sale price be increased to $50 \%$, that the maximum rate be removed and finally that a specific tax of $\$ 0.02$ per cigarette be introduced into the system.

A final conference was held in Ouagadougou on 10 and 11 July 2014, which was devoted to a review and validation of the draft directive on the harmonisation of excise duties. It brought together representatives of the 15 ECOWAS member countries, of WAEMU, German Cooperation (GIZ), CRES and resource persons. The various articles of the directive were examined and amended.The conference urged the ECOWAS Commission to accelerate the adoption process. Unfortunately, a delay then ensued in the final adoption due to the Ebola epidemic in West Africa, which stopped travel and had a disruptive effect, diverting attention from regional processes. However, the new guidelines were finally adopted in December 2017 by the two sub-regional organisations (ECOWAS and WAEMU).

\section{The research evidence generated}

The research undertaken by the country teams produced three main documents - country profiles, a regional synthesis and a position paper, referred to as 'arguments' in French (CRES, 2013a, 2013b, 2013c).

The country profiles covered evidence around key issues such as consumption of tobacco products; the economic importance of tobacco production; the inefficiency of applied taxation; the relationship between tax increases and 
price increases; and the challenges related to gathering data and measuring the value of smuggling of tobacco products. As well as the 15 country profiles, stakeholders requested a single West African regional profile on tobacco taxation which showed the differences and similarities between countries.

The reports of the national research teams in each of the 15 countries, the resulting regional synthesis and the various workshops showed that reform must focus on the adjustment and harmonisation of tax levels and the tax structure to converge towards common objectives for controlling tobacco consumption. The advocacy document (CRES, 2013c) used the results of these various studies, along with elements from the international literature on tobacco taxation, to provide West African leaders with arguments for tobacco tax reform and the best practices available to them to carry it out. These included, for example, a reallocation of household spending away from tobacco towards health insurance, which would go a long way towards ensuring that basic health care is affordable for a significant proportion of the population. The document also showed that there was a lot of inefficiency in tax uptake. The WHO has set as its main criterion for judging the effectiveness of the tax system on tobacco that tax should be at least $70 \%$ of the retail price of cigarettes. Of the 15 ECOWAS countries, only two collected more than $40 \%$ of the retail price of cigarettes, while this is at least $60 \%$ in some European countries. In addition, the main reasons for the ECOWAS countries' delay in raising taxation were identified and explained.The first is that tax increases are often not regularly adjusted upwards. Increasing the price of tobacco products through taxation is a very effective tool for reducing consumption, but because of the addictive nature of these products and the behaviour of tobacco manufacturers, it is important to increase the value of the price strongly and continuously to reduce consumption.

The second reason was the inefficiency of applying only an ad valorem tax. The regional legislation in force in the sub-region only provided for excise duties in value terms. No West African country had achieved the target of total taxes representing $70 \%$ of the selling price of the cigarette packet.

The third reason was the weakness of the tax base. The ex-works price declared by the tobacco industry did not even represent half of the final selling price. Taxation based on the ex-works price can in no way achieve the objective of a tax share in the retail price.

\section{A clear example of use - but the story is not finished}

The final version of the tax adopted by ECOWAS was based on the position paper. The process led to specific recommendations based on evidence and was carried out in a manner that built the commitment of the technical staff, who had to develop the proposal and implement it, and the policy makers who had to adopt the directive. According to the representative of the ECOWAS Customs Commission,

To be able to adopt the directive, it was necessary to make technical reports to convince the states. However, ECOWAS is not a research centre. It is 
therefore thanks to the documents produced ... that we were able to develop them and propose a new range of taxes.

The country profile documents were used in Senegal

to inform the Minister of Health about the existence of possible tax niches through tobacco that could finance health.... Civil society has emerged strengthened by this project. His speeches, which focused on raising awareness among targeted audiences, particularly schoolchildren, have now been expanded to include taxation as the best way to reduce tobacco consumption. These details have greatly helped in political decision making.

(Tobacco focal point, Senegal Ministry of Health)

A respondent who represented Senegalese civil society indicated that civil society is now invited to participate in technical meetings with the tobacco industry, enabling them to compete with the tobacco industry.

The project also opened opportunities for members of the national teams:

I was approached as a resource person for a study on smuggling, commissioned by customs, and the research and analysis tools from the Benin country profile were used in the methodology. I also participated in programmes on national television with civil society and the Ministry of Health to inform national opinion on certain aspects, mechanisms to reduce tobacco consumption, updating the law, etc. My contribution was based on the results of the studies carried out as part of the tobacco project.... I am often asked to give my opinion on tobacco issues because I led the national research team.

(The leader of Benin Team)

According to the representative of fiscal administration in the Burkina Faso team, 'The Legislation Directorate worked on amending the code for the increase in tobacco tax based on data collected through the CRES project. Currently we are in the process of increasing taxes to reach the FCTC rate.' (Fiscal administration representative for Benin).

An unintended consequence of the new tobacco fiscal directive process is that greater emphasis has been placed on research into tobacco use in West Africa, with more and more research institutes interested in the topic and doctoral and master's theses supported on these topics. The team researcher in Senegal said:

My impression has changed considerably. I think that researchers in economics and even sociology can indeed intervene to counter the purchase of cigarettes, which are a heavy expense, and convince public decision makers to fight smoking through tax collection. With regard to the involvement of economists, researchers can have a significant impact and guide public decisions to eradicate the scourge.

(Team researcher from Senegal) 
Tax administrations saw the taxation of tobacco products as an instrument for collecting tax revenue, while civil society actors and ministries of health focused on the health dangers. The bringing together of these stakeholders has shifted the philosophy towards the consideration of taxation as a tool for protecting public health. These stakeholders have thus integrated into their behaviour that tobacco use must be analysed over a long- or medium-term horizon to take into account all relevant aspects in political decision making (CRES, 2014).

After the adoption of the new regional directive, each country's tax administration had to incorporate it into national legislation. However, progress has been slow. Nigeria has introduced a specific tax but keeps the ad valorem tax below the minimum imposed by the new directive. Senegal and Ghana have increased their ad valorem tax rates without introducing a specific tax.

The slow adoption and transposition of the directive into national legislation may be due mainly to two factors. First, as the representative of the ECOWAS Commission pointed out, ECOWAS management teams change every four years. The new management team takes time to understand, carry out and enforce decisions made by their predecessors. Second, the new, more binding directive runs counter to the interests of the tobacco industry, which is trying to influence decision making by arguing that the tobacco industry contributes to the countries' economies through job creation and tax revenue. Its interventions can delay decision making. Lobbying by the tobacco industry delayed the process but the relevance of the evidence and the determination of stakeholders finally won. Thus, stakeholders have changed their vision of tobacco.

Finally, a steering committee must be set up to monitor the process of transcription into national legislation and ensure that the laws are applied. This regional committee is not yet in place and some pressure is needed to ensure it gets established. CRES has initiated a new project to address this.

The purpose of the action-research project was to protect people's health from the negative effects of tobacco. One of the outcomes of this project was to measure the costs of tobacco through non-communicable diseases. The results showed that while tobacco caused some of these diseases, food was a large contributing factor. Thus, CRES has launched a new action-research project in Senegal on the food system and non-communicable diseases.

\section{The factors enabling and hindering evidence use}

\section{What types of use do we see?}

In this book we have characterised uses of evidence as instrumental, conceptual, process and symbolic (see Chapter 2). We do see instrumental use, in that the form of the directive was largely drafted as part of the action-research process. The specific proposal from the simulations of the tax rates to use was also adopted in the directive.

Underlying instrumental use was significant conceptual use. As a result of the process, stakeholders had a much better understanding of the challenges arising 
from tobacco consumption, the limited benefits to the economy compared to the costs to the state, and possible modalities of taxation. This understanding led to the approval of the directive and tax rates. As taxation is a regional issue, each country realised that regional tax harmonisation was the only way to control consumption and reduce illicit trade, and that a regional strategy would have more impact. Another form of conceptual use that emerged is that local evidence on tobacco use is now produced and disseminated widely which makes it possible to talk about real statistics from the region. In terms of research, we can see a flowering of documents that use the statistics produced by CRES. Countries have also used their greater understanding to inform their participation in international meetings such as the Conference of the Parties to the FCTC (Civil society respondent).

The process also greatly raised the profile of the dangers of tobacco consumption in the region, which helped to counteract the lobbying from the tobacco industry. This is an example of positive symbolic use.

In terms of process use, the establishment of research units in each country led to countries acknowledging the importance of the evidence process.

\section{How evidence use was promoted}

A variety of interventions promoted the use of evidence (see Table 12.1), but there were four main levers. An important first lever was the process facilitation role played by CRES, along with key champions in CRES and ECOWAS. The CRES director used his contacts to bring together all the key players in the fight against tobacco. He understood the multidisciplinary aspects of tobacco control, the need to produce relevant rigorous evidence and the need to master political decisionmaking mechanisms. He involved his academic colleagues specialising in law and sociology for the draft law in Senegal and the smoking ban in Touba. He used his relationship with the ECOWAS representative to work on tariffs in ECOWAS. The collaboration between CRES and ECOWAS helped them to understand the steps to be taken for a change of directive. The director of CRES also seized on the opportunity of a meeting with the then president of the Republic of Senegal to raise the president's awareness of the need for a new law to control tobacco use.

CRES obtained funding for the action research and immediately started to address the main shortcomings highlighted in the prior situational analysis, namely the lack of synergy in tobacco control between researchers and other stakeholders like civil society, ministries of health, fiscal and customs administrations, and members of Parliament at the national and regional levels. CRES had an understanding of how this synergy could be built that could lead to a new tobacco directive. This process began with the involvement of all stakeholders from the beginning through a methodological workshop to upgrade their knowledge in terms of tobacco use and especially tobacco taxation. This enabled all stakeholders to discuss the subject and to understand actual practice in the region. A key champion in ECOWAS, the chairman of the Customs Commission, indicated,

I had no knowledge of this issue. I started to get a better idea of the tobacco issue at the first methodological workshop. It was with the country profiles 
Table 12.1 Use interventions and their influence

\begin{tabular}{|c|c|}
\hline Intervention & Effect \\
\hline $\begin{array}{l}\text { Process facilitation } \\
\text { and knowledge } \\
\text { brokering }\end{array}$ & $\begin{array}{l}\text { CRES facilitated the overall process over a number of years, } \\
\text { managing the IDRC-funded project and using it to conduct } \\
\text { the research, liaise with stakeholders, organise effective events } \\
\text { and problem-solve to take the process to completion. Many of } \\
\text { the following process elements were intended to help interaction } \\
\text { and building of trust between stakeholders, to agree and work } \\
\text { together on a common cause. }\end{array}$ \\
\hline $\begin{array}{l}\text { Creation of a civil } \\
\text { society coalition } \\
\text { in Senegal to } \\
\text { support action on } \\
\text { tobacco taxation }\end{array}$ & $\begin{array}{l}\text { A key feature with civil society was the need to unite and advocate } \\
\text { for tobacco control in-country. A coalition was established } \\
\text { which helped to create this. }\end{array}$ \\
\hline $\begin{array}{l}\text { Scientific } \\
\text { committee, } \\
\text { steering } \\
\text { committee } \\
\text { comprising key } \\
\text { stakeholders }\end{array}$ & $\begin{array}{l}\text { These structures brought together government and non- } \\
\text { government stakeholders and helped to build agreement, } \\
\text { commitment and trust in relation to the credibility and importance } \\
\text { of the process. }\end{array}$ \\
\hline $\begin{array}{l}\text { Multidisciplinary } \\
\text { research teams } \\
\text { were set up in } \\
\text { each of the } 15 \\
\text { countries }\end{array}$ & $\begin{array}{l}\text { Multidisciplinary teams ensured rigour in producing the evidence } \\
\text { and access to tax and customs data. The recommendations gave } \\
\text { decision makers confidence in their decision making in } 2011 \text {. } \\
\text { These teams increased the ability of countries to generate and } \\
\text { use evidence, as they undertook much of the research. The } \\
\text { composition of the teams made it easier to access and collect the } \\
\text { required information on each country and strengthened country } \\
\text { ownership of the data and process. }\end{array}$ \\
\hline $\begin{array}{l}\text { Database of } \\
\text { tobacco control } \\
\text { stakeholders in } \\
\text { Senegal }\end{array}$ & $\begin{array}{l}\text { CRES initiated a database which they made available to civil } \\
\text { society to make civil society actors aware of who else is working } \\
\text { in the tobacco space. This tool has contributed to the creation of } \\
\text { partnerships between the actors. }\end{array}$ \\
\hline $\begin{array}{l}\text { Targeted events at } \\
\text { a technical level } \\
\text { and political level }\end{array}$ & $\begin{array}{l}\text { A series of regional events was organised, some with technical } \\
\text { staff, some with high-level politicians, some with members } \\
\text { of Parliament. The location was rotated between countries to } \\
\text { maximise ownership. These events developed and agreed content, } \\
\text { built ownership and agreement at different levels, and fostered trust } \\
\text { between technical staff, politicians and non-state actors. Getting } \\
\text { key decisions from decision makers at these events made it easier } \\
\text { to formalise decisions later. }\end{array}$ \\
\hline $\begin{array}{l}\text { Collaboration } \\
\text { between state and } \\
\text { non-state actors } \\
\text { to counter the } \\
\text { tobacco lobby }\end{array}$ & $\begin{array}{l}\text { CRES received examples of letters sent by the tobacco industry } \\
\text { to government and collaborated with civil society in drafting } \\
\text { responses. This built government's ability to respond as well as } \\
\text { trust between state and non-state actors. }\end{array}$ \\
\hline $\begin{array}{l}\text { Reports } \\
\text { consolidated } \\
\text { arguments for } \\
\text { policy makers }\end{array}$ & $\begin{array}{l}\text { The position paper summarised the arguments for policy makers, } \\
\text { which helped to build understanding and awareness of the costs } \\
\text { and benefits around tobacco and the options available. }\end{array}$ \\
\hline
\end{tabular}


Table 12.1 (Continued)

\begin{tabular}{|c|c|}
\hline Intervention & Effect \\
\hline Format of reports & $\begin{array}{l}\text { A policy note was produced for each country profile and for key } \\
\text { recommendations. The policy notes were in a four-page format, } \\
\text { written in both English and French, to make the key results } \\
\text { accessible and help policy makers be aware of them. }\end{array}$ \\
\hline Reports public & $\begin{array}{l}\text { All reports produced by CRES in this process are publicly accessible } \\
\text { at www.cres-sn.org, which promoted access to evidence. }\end{array}$ \\
\hline $\begin{array}{l}\text { Knowledge- } \\
\text { brokering role of } \\
\text { CRES }\end{array}$ & $\begin{array}{l}\text { CRES played a key role in knowing the research world and } \\
\text { linking the research world with the public sector and political } \\
\text { world. They ensured that effective research teams were set up } \\
\text { in each country, that good evidence was generated and that it } \\
\text { was disseminated in an accessible form, and so easy to access and } \\
\text { use. They organised events where this evidence was tabled, at } \\
\text { technical and political level. They built trust with governments } \\
\text { and the commission and built the capability and motivation of the } \\
\text { technical staff and politicians who participated. }\end{array}$ \\
\hline $\begin{array}{l}\text { Use of WHO } \\
\text { standards as a } \\
\text { reference }\end{array}$ & $\begin{array}{l}\text { Being aware of WHO standards provided an external benchmark, } \\
\text { for example, in deciding what tax levels could be/should be. } \\
\text { This provided some motivation for change as well as trust that } \\
\text { the proposed recommendations were appropriate. }\end{array}$ \\
\hline $\begin{array}{l}\text { Use of peer } \\
\text { comparison to } \\
\text { promote use }\end{array}$ & $\begin{array}{l}\text { The comparison of the } 15 \text { countries in reports and in the } \\
\text { conferences allowed participants to learn what others were } \\
\text { doing and introduced some level of competition to be seen to } \\
\text { be doing well. }\end{array}$ \\
\hline
\end{tabular}

Note: Change mechanisms are highlighted in italics.

that I learned about the harmful effects of tobacco, especially on young people and vulnerable people.

This process facilitation involved a second lever, the inclusion of key people in the process as the intention was that the Council of Ministers would change the tobacco taxation directive on the basis of evidence. In order to achieve this, it was important that the technical staff who had to convince the ministers of the need for this change were involved throughout. Hence, officials from the ministries responsible for the application of taxation had to be involved in the steering committees, be part of the research generation process, participate in key events and so forth.

The integration of the technical experts from the administrative bodies who would analyse the proposals to be made to the ministers was facilitated by their inclusion in multidisciplinary national research teams that were expected to produce most of the evidence.

The third lever to promote use of the evidence was the organisation of workshops and conferences that brought together the 15 ECOWAS member countries led by CRES. All 15 ECOWAS countries were represented by a delegation of at least two people from the tax and customs administrations and the country's ministry of health.The host city for these events was rotated, with workshops and conferences held in Ouagadougou, Dakar and Abidjan. Each of these events was opened 
by eminent people from the host country in the presence of high-level representatives from community institutions. For example, the two advocacy workshops, the first bringing together tax, customs and health administrations and the second the parliamentarians, held in Abidjan, were attended by the chief of staff of the Minister of African Integration, a vice president of the National Assembly of Côte d'Ivoire, a vice president of the Ivorian Senate, the chairman of the ECOWAS Customs Commission and the representative of the WAEMU Commission.

The fourth lever was the presentation of the results in the form of easy to read policy notes to better disseminate the results. Each country profile was the subject of a policy note in a brief, four-page format focusing on policy recommendations. The policy notes were written in both English and French.

\section{Facilitators and barriers to the use of evidence}

The three key facilitators of the use of evidence

\section{RATIFICATION OF THE WHO FRAMEWORK CONVENTION ON TOBACCO} CONTROL AT REGIONAL LEVEL

When the action-research project on tobacco taxation in West Africa began, all ECOWAS countries had ratified the WHO FCTC which identified taxation as the most effective way to reduce consumption. Thus, there was a strong commitment by each country to fight the consumption of tobacco products. The need to fulfil this commitment provided an environment conducive to the adoption of a new directive on the taxation of tobacco products and contributed to the active participation of governments.

\section{PARTICIPATION IN INTERNATIONAL MEETINGS}

Since ratification of the FCTC, tobacco control stakeholders have participated in international meetings such as the Conference of the Parties to the FCTC and the World Tobacco Conference. These meetings raised awareness of the need for strong commitment against tobacco, and demonstrated that the international community has decided to take action. According to the civil society respondent, the discussions at these conferences provided an opportunity to hear about the strength of taxation as a means of tobacco control.

\section{THE ROLE OF CHAMPIONS}

Two main champions were the driving force behind the new tobacco tax directive - the director of CRES and the chairman of the ECOWAS Customs Commission. The director of CRES designed the action-research project to create synergy between research, advocacy and political decision making. CRES's role in process facilitation, led by the director, is described earlier. Second, agreement of a new directive on the taxation of tobacco would not have been possible without the political will of the chairman of the ECOWAS Customs Commission. 
At the outset he had no knowledge of the issue, but he was committed to providing ECOWAS countries with an effective tool to control tobacco. He mobilised ECOWAS delegations for the meetings and ensured the preparation of technical notes for the discussions. Once the directive was ready for adoption, despite the considerable delays caused by the Ebola virus crisis in the ECOWAS region, he continued to work towards the final adoption of the process.

The three key barriers to the use of evidence

THE EBOLA CRISIS

After analysis and validation of the draft directive in 2014, the Ebola virus crisis hit West Africa. As some ECOWAS countries had Ebola cases, ECOWAS was forced to suspend all inter-state gatherings to prevent the spread of the disease. This situation slowed down the process of adopting the directive, which delayed the process for about three years. However, as the two key champions were still in their positions in ECOWAS and in CRES, it was relatively easy to pick up the process again.

\section{INTERFERENCE FROM THE TOBACCO INDUSTRY}

The tobacco industry took advantage of the Ebola crisis to try to discredit the process. Letters were sent to a few ministers to discourage them from adopting the draft regional directive. The lobbyists denounced the role played by CRES, arguing that it had replaced the administrations as the driver of the process. CRES and civil society shared these letters and helped government to respond to these letters, and the tobacco industry did not manage to derail the process.

\section{THE EXISTENCE OF TWO PARALLEL DIRECTIVES}

Both ECOWAS and WAEMU developed directives. The WAEMU directive does not have a specific tax, just an ad valorem figure. Countries belonging to both regional bodies can apply the directives of both. However, this does not make the application of the same directive in the 15 ECOWAS countries any easier. WAEMU, being an economic and monetary union, has more opportunities to meet, because it deals with more economic issues and is more closely integrated. The issues around these multiple tax jurisdictions are discussed in Blecher and Drope (2014).

\section{Conclusions and lessons}

\section{How did the context and intervention influence the use of evidence}

First, we apply the realist approach to look at what mechanisms are likely to lead to successful outcomes in what contexts. The mechanisms applied included the generation of evidence and interventions to maximise the likelihood of use. 
The hypothesis was that these would lead to the outcomes of changes in individual/organisational motivation, in capability and in the opportunity to use evidence, which would lead to behaviour change in individuals/organisations/ systems, which would result in policy performance and wider systems change.

The context in this case was characterised by fragmented stakeholders with differing worldviews, notably from tax and health perspectives, 15 different countries, and a contentious topic with a strong industry lobby. On a regional dimension, the signing of the FCTC provided some incentive for countries to comply.

Interventions to promote use started with the approval of the action-research project, and an immediate focus on bringing stakeholders together, the start of strong process facilitation by CRES through the project, coupled with an institutional champion in ECOWAS. A series of processes and events was used to build consensus across the 15 countries, helped by the convening power of ECOWAS, and this collective power helped to offset the lobbying from the tobacco industry. Evidence was generated through the creation of multidisciplinary virtual research units in each country, which helped to create ownership as well as generate rigorous evidence. The research units generated country profiles, a synthesis, models of tax rates and eventually a rationale/argument for a new directive and for the eventual revised tax rates. Use interventions after the evidence was produced included producing policy briefs to summarise the argument and recommendations, production of a draft directive, and tabling these at technical and political regional committees.

In terms of outcomes, ultimately the directive was adopted, a major achievement, and an example of instrumental use of the recommendations. We see increased capability of country stakeholders to work together, to produce evidence, and conceptual use of the evidence to argue for tobacco control at international fora. The need to address the Framework Convention provided the opportunity, which was enhanced by support from high levels in ECOWAS. The process stimulated the motivation of stakeholders to produce and approve the directive, even despite the loss of momentum with the interregnum during the Ebola epidemic. Domestication of the directive into country legislation is the next battle.

\section{Emerging lessons}

Some of the emerging lessons for evidence use from this case include:

- Undertaking a situation analysis at the beginning was important, through which the multidisciplinary aspect of the tobacco issue was identified, as well as key stakeholders.

- The actual evidence generation was probably less than half the effort. Highquality process facilitation to support a multi-stakeholder partnership was essential, championing and facilitating processes over time. These skills are 
not usually present in government, and such processes can be led by nonstate actors, where the key government champion is able to ask for support.

- The inclusion of all stakeholders, through a participatory approach, from the beginning of the process created a real synergy between the actors allowing everyone to drive the fight that was needed.

- Action-research processes are potentially very powerful, where as much attention is given to the use interventions and process support as to evidence generation itself, and the evidence is located within a wider process.

- The facilitator needs to bridge the understanding of evidence with a good knowledge of the functioning of government (and, in this case, regional institutions) and work in an empowering way. According to the director of CRES, if we did not know how the two regional organisations work, how the different countries work with these institutions, I do not think we could do this mobilisation work in such a short time'.

- The lead organisation must be credible. CRES gained credibility in all the member states through prior work on negotiations for an economic partnership agreement. This made it much easier to mobilise the regional organisations and the 15 member states (CRES director).

- It is important to have champions who can carry the momentum effectively over a number of years - in this case, an institutional champion and an evidence/knowledge broker champion.

- Coalitions of state and non-state actors can be very powerful, if they can develop a common vision, and the process is well supported. This is particularly important for sectors where industry lobbies are powerful, such as around tobacco, climate change, mining and so forth.

- Piloting processes in one country can be helpful prior to applying at the regional level, and this can even work across language and cultural divides.

- An international/regional agreement can be used to help large-scale change to happen.

The process of adopting a new directive on tobacco taxation in West Africa has been very rewarding for all stakeholders in tobacco control. The case study provides a number of lessons and demonstrates that it is possible to use evidence to change public policies. However, having good evidence was only one of a number of necessary factors.

The adoption of a new directive on the taxation of tobacco products in ECOWAS is a very significant step forward in tobacco control. ECOWAS countries have the opportunity to use the most effective means to reduce tobacco consumption. This must make it possible to meet the commitments made when ratifying the Framework Convention. Now it remains for ECOWAS countries to transpose the new directive into national legislation in order to implement it, and in Senegal's case to enforce the law. This battle is not yet won. 


\section{Notes}

1 Consortium pour la Recherche Economique et Sociale.

2 This focused on undertaking a situation analysis to assess current tobacco use, the dynamics of tobacco farming and existing tobacco control policies (including their level of implementation) in 10 to 14 sub-Saharan African countries. At the same time, it endeavoured to build the technical capacity of African researchers to gather, synthesise and analyse data at the country and the regional level.

See www.idrc.ca/en/project/african-tobacco-situation-analyses.

\section{References}

ASTA. 2010. Rapport technique final, Analyse Situationnelle sur le tabac au Sénégal. Dakar, Senegal: Consortium pour La Recherche Economique et Sociale.

Blecher, E. and Drope, J. 2014. The rewards, risks and challenges of regional tobacco tax harmonisation. Tobacco Control, 23, e7-e11. https://doi.org/10.1136/tobaccocontrol2013-051241

Chaloupka IV, F.J., Peck, R., Tauras, J.A., Xu, X. and Yurekli, A. 2010. Cigarette excise taxation: The impact of tax structure on prices, revenues, and cigarette smoking. Cambridge, MA: National Bureau of Economic Research Working Paper No. 16287. https://doi.org/ 10.3386/ w16287

CRES. 2013a. Profils-pays sur la fiscalité du tabac en Afrique de l'Ouest. Dakar, Senegal: Consortium pour La Recherche Economique et Sociale. Retrieved from www.cres-sn.org.

CRES. 2013b. Synthèse régionale des profils-pays sur la fiscalité du tabac en Afrique de l'Ouest. Dakar, Senegal: Consortium pour La Recherche Economique et Sociale. Retrieved from www.cres-sn.org

CRES. 2013c. Argumentaire pour un changement de la fiscalité sur les produits du tabac. Dakar, Sénégal: Consortium pour La Recherche Economique et Sociale. Retrieved from www. cres-sn.org

CRES. 2014. Rapport technique 'Projet régional de recherche-action sur la taxation des produits de tabac en Afrique de l'Ouest'. Dakar, Sénégal: Consortium pour La Recherche Economique et Sociale. Retrieved from www.cres-sn.org

Economic Community of West African States. June 2009. Directive C/DIR.2/06/09 On Excise Tax harmonization.

Goodchild, M., Nargis, N. and Tursan d'Espaignet, E. 2018. Global economic cost of smoking-attributable diseases. Tobacco Control, 27(1), 58-64.

IARC. 2011. Effectiveness of tax and price policies for tobacco control. IARC Handbooks of Cancer Prevention: Tobacco Control. WHO International Agency for Research on Cancer.

WHO. 2015. WHO report on the global tobacco epidemic: Raising taxes on tobacco. Geneva: World Health Organisation. 